\title{
Antiviral activity of Siberian wild and cultivated plants
}

\author{
Natalya Mazurkova ${ }^{{ }^{*}}$, Mariya Protsenko $^{1}$, Irina Lobanova $^{2}$, Ekaterina Filippova ${ }^{1}$, and \\ Galina Vysochina ${ }^{2}$ \\ ${ }^{1}$ State Research Center of Virology and Biotechnology VECTOR, w.v. Koltsovo, Novosibirsk region, \\ 630559, Russia \\ ${ }^{2}$ Central Siberian Botanical Gardens SB RAS, 630090 ul. Zolotodalinskaya, 101, Novosibirsk, Russia
}

\begin{abstract}
The article presents data on the antiviral activity of ethanol and aqueous extracts isolated from the herb plants Dracocephalum nutans, Glechoma hederacea, Melissa officinalis, Berteroa incana, Aegopodium podagraria, and Veronica longifolia against the A/Aichi/2/68 (H3N2) and A/chicken/ Kurgan/05/2005 (H5N1) subtypes of influenza A virus (IAV) in MDCK cell culture. It was found that the ethanol extracts of Glechoma hederacea, Berteroa incana, and Aegopodium podagraria have the antiviral activity in vitro in MDCK cell culture against H3N2 subtype of IAV. The aqueous extracts of Glechoma hederacea, Melissa officinalis, Aegopodium podagraria, and Veronica longifolia and ethanol extracts of Berteroa incana and Veronica longifolia are active against H5N1 subtype of IAV. None of the extracts of Dracocephalum nutans showed significant activity against the studied subtypes. The greatest efficiency was shown by the ethanol extract of Aegopodium podagraria against the H5N1 subtype and aqueous extracts from Glechoma hederacea and Melissa officinalis.against the H3N2 subtype. The ethanol extract of Berteroa incana has a high activity against both IAV subtypes, which makes this sample the most promising for creating new drugs for the prevention and treatment of influenza virus.
\end{abstract}

\section{Introduction}

The creation of new effective antiviral drugs is one of the most important and urgent tasks of modern medical science because of the accelerated evolution of viruses and almost no efficiency of antibiotics for viral diseases.

From ancient times to the present day, mankind uses plants to treat various diseases. Herbal preparations have low toxicity, a wide range of biological effects on the body, and minimum side effects compared to synthetic drugs. In recent years, there has been increased interest in the development of herbal medicines for the prevention and treatment of viral infections.

Currently, some studies confirm an antiviral effect of both extraction preparations and individual plant substances. Our previous research has proved that extracts of plants, such

\footnotetext{
* Corresponding author: mazurkova@,vector.nsc.ru
} 
as Alchemilla vulgaris, Agrimonia pilosa, Geum rivale, Spiraea salicifolia, Lythrum virgatum, Veronica krylovii, Monarda fistulosa, and Salvia officinalis show the in vitro antiviral activity against influenza virus, herpes simplex virus type 1 and 2 , and orthopoxviruses (smallpox and mouse pox viruses) [1-6].

The goal of the work was to study the antiviral activity of extracts of Siberian plants Dracocephalum nutans, Glechoma hederacea, Melissa officinalis, Berteroa incana, Aegopodium podagraria, and Veronica longifolia against the H3N2 and H5N1 subtypes of influenza A virus.

\section{Materials and methods}

The objects of research were herbs of wild and cultivated plants, which were collected in 2018 on the territory of the Toguchinsky district in the Novosibirsk region. These herbs are Berteroa incana (L.) DC (hiccup gray-green), Glechoma hederacea L. (ivy-shaped budra), Dracocephalum nutans L. (drooping dragonhead) (village Zheleznodorozhnyi), Aegopodium podagraria L. (goutweed ordinary), Veronica longifolia L. (veronica longleaf), Melissa officinalis L. (melissa medicinal) (village Berezovka).

Dry extracts are the most rational type among phytopreparations. They are relatively easy to use, store, and transport. It is possible to use dry extracts in optimal doses due to the high content of biologically active compounds and combine them with other functional products at the manufacturing stage.

For this purpose, we used our previously developed technology. Ethanol extracts were prepared by four-fold extraction of dried crushed plant raw materials with $70 \%$ ethanol at $60^{\circ} \mathrm{C}$ with a reverse refrigerator in a water bath for $4 \mathrm{~h}$. The ratio of raw materials to ethanol was 1 : 50. When preparing aqueous extracts, the plant raw materials were extracted twice with distilled water at $95^{\circ} \mathrm{C}$ with a reverse refrigerator in a water bath for 2 $\mathrm{h}$. The cooled liquid extracts were filtered from the raw materials through a glass filter, evaporated on a rotary evaporator, and dried in a drying cabinet at $60^{\circ} \mathrm{C}$ to the humidity of $5 \%$.

The resulting ethanol and aqueous extracts were tested for toxicity and antiviral activity against the A/Aichi/2/68 (H3N2) and A/chicken/Kurgan/05/2005 (H5N1) subtypes of IAV in the transplanted cell culture of Madin-Darby Canine Kidney (MDCK). The maximum tolerated concentrations of extracts were evaluated by measuring the toxic effects of the diluted samples in the monolayer of the MDCK cell culture. For this purpose, the original samples were diluted 2, 5, 10, 50, 100, 500, 1000, and 10000 times with the DMEM medium (Biolot LLC, Russia). After dilutions, the samples $(100 \mu \mathrm{L})$ were loaded into microplate wells and placed in a thermostat at $37^{\circ} \mathrm{C}, 5 \% \mathrm{CO}_{2}$, and $100 \%$ humidity for $2 \mathrm{~h}$. The toxic effects in the monolayer of the MDCK cells were evaluated using an inverted microscope.

The virus-containing allantoic fluids (VAF) of the studied IAV subtypes were ten-fold diluted from $10^{-1}$ to $10^{-8}$ with the DMEM medium that contained trypsin $(2 \mu \mathrm{g} / \mathrm{mL})$ (TPCK, Sigma, USA). To evaluate the antiviral activity, the prepared sample extract in the chosen dilution $(50 \mu \mathrm{L})$ was introduced into the monolayer of the MDCK cells in the DMEM medium with trypsin $(2 \mu \mathrm{g} / \mathrm{mL})$, followed by the addition of each of the diluted VAF solutions. The cells were incubated at $37^{\circ} \mathrm{C}$ in $5 \% \mathrm{CO}_{2}$ in a TS- $1 / 80 \mathrm{SPU}$ thermostat (Russia) for two days. The cytopathic action in each well was evaluated using an inverted microscope. The presence of the virus in the culture medium was detected by the hemagglutination reaction with a $1 \%$ suspension of chicken red blood cells.

The virus titers were evaluated in terms of the log of $50 \%$ of tissue cytopathic doses $(\mathrm{mL})$ in the control and the experiment $\left(50 \%\right.$ infecting doses, $\mathrm{ID}_{50}$, in vitro without and with a sample, respectively): 


$$
\mathrm{ID}=\mathrm{ID}_{50}(\text { contr })-\mathrm{ID}_{50}(\exp )(\log )
$$

The MDCK cells cultured in the DMEM culture medium with trypsin $(2 \mu \mathrm{g} / \mathrm{mL})$ and the IAV strains (A/Aichi/2/68 and A/chicken/Kurgan/05/2005) diluted from $10^{-1}$ to $10^{-8}$ without applying an extract were used as controls.

According to the Guidelines for experimental preclinical study of new pharmacological substances [8], drugs that cause a decrease in the infectivity of viruses in cell culture by at least $2.0 \mathrm{log}$ are promising for further in vivo studies.

Statistical processing and comparison of the results of virological studies were performed using standard methods [9] and the computer software Statistica 6.0 package (StatSoft Inc. 1984-2001) [10] with an assessment of the reliability of differences at $p \leq$ 0.05 .

\section{Results and discussion}

Ethanol and aqueous extracts of plants have been shown to exhibit low toxicity in the MDCK cell culture. The maximum tolerated concentration of the dry plant extracts for this cell culture was in the range of $1-5 \mathrm{mg} / \mathrm{mL}$.

We studied the inhibition of reproduction of the A/chicken/Kurgan/05/2005 (H5N1) and A/Aichi/2/68 (H3N2) IAV subtypes in the MDCK cell culture under the action of ethanol and aqueous extracts of Dracocephalum nutans, Glechoma hederacea, Melissa officinalis, Berteroa incana, Aegopodium podagraria, and Veronica longifolia. The results are presented in Tables 1 and 2. We revealed the antiviral effect of the ethanol extracts of Glechoma hederacea and Aegopodium podagraria against the A/Aichi/2/68 (H3N2) subtype and the ethanol extract of Veronica longifolia against the A/chicken/Kurgan/05/2005 (H5N1) subtype. The Berteroa incana extract was active against both subtypes (Table 1).

Table 1. Antiviral effect of ethanol plant extracts in MDCK cell culture against A/Aichi/2/68 (H3N2) and A/chicken/Kurgan/05/2005 (H5N1) subtypes of IAV

\begin{tabular}{|c|c|c|c|c|c|}
\hline \multirow{2}{*}{ Plant species } & \multirow{2}{*}{$\begin{array}{c}\text { Concentration, } \\
\mathrm{mg} / \mathrm{mL}\end{array}$} & \multicolumn{2}{|c|}{$\mathrm{A} /$ Aichi/2/68 $(\mathrm{H} 3 \mathrm{~N} 2)$} & \multicolumn{2}{c|}{$\begin{array}{c}\mathrm{A} / \text { chicken/Kurgan/05/200 } \\
5(\mathrm{H} 5 \mathrm{~N} 1)\end{array}$} \\
\cline { 3 - 6 } & $\begin{array}{c}\operatorname{lgTCD}_{50} / \mathrm{mL} \pm \\
\mathrm{Sm}\end{array}$ & $\mathrm{NI}, \log$ & $\begin{array}{c}\operatorname{lgTCD}_{50} / \mathrm{mL} \\
\pm \mathrm{Sm}\end{array}$ & $\mathrm{NI}, \log$ \\
\hline $\begin{array}{c}\text { Dracocephalum } \\
\text { nutans }\end{array}$ & 1.0 & $5 \pm 0.29$ & 1.25 & $4.5 \pm 0.0$ & 1.75 \\
\hline $\begin{array}{c}\text { Glechoma } \\
\text { hederacea }\end{array}$ & 3.33 & $3 \pm 0.29$ & 3.25 & $4.5 \pm 0.29$ & 1.75 \\
\hline Melissa officinalis & 3.33 & $5.5 \pm 0.0$ & 0.75 & $4.5 \pm 0.0$ & 1.75 \\
\hline Berteroa incana & 5.0 & $2 \pm 0.29$ & 4.25 & $3.0 \pm 0.0$ & 3.25 \\
\hline $\begin{array}{c}\text { Aegopodium } \\
\text { podagraria }\end{array}$ & 1.0 & $1.5 \pm 0.0$ & 4.75 & $4.5 \pm 0.29$ & 1.75 \\
\hline Veronica longifolia & 2.5 & $4.5 \pm 0.0$ & 1.75 & $3.5 \pm 0.29$ & 2.75 \\
\hline Control & - & $6.25 \pm 0.25$ & - & $6.25 \pm 0.38$ & - \\
\hline
\end{tabular}

Note: $\log \mathrm{TCD} 50 / \mathrm{mL}$ is a decimal logarithm of $50 \%$ tissue cytopathic dose; Sm is standard deviation; NI is a virus neutralization index.

The aqueous extracts of Glechoma hederacea, Melissa officinalis, Aegopodium podagraria, and Veronica longifolia exhibited the antiviral activity against the A/chicken/Kurgan/05/2005 (H5N1) subtype. None of the aqueous extracts showed significant activity against the A/Aichi/2/68 (H3N2) subtype (Table 2). Neither ethanol nor aqueous extracts of Dracocephalum nutans showed any noticeable activity against studied IAV subtypes. 
Table 2. Antiviral effect of aqueous plant extracts in MDCK cell culture against A/Aichi/2/68 (H3N2) and A/chicken/Kurgan/05/2005 (H5N1) subtypes of IAV

\begin{tabular}{|c|c|c|c|c|c|}
\hline \multirow{2}{*}{ Plant species } & \multirow{2}{*}{$\begin{array}{c}\text { Concentration, } \\
\mathrm{mg} / \mathrm{mL}\end{array}$} & \multicolumn{2}{|c|}{$\mathrm{A} /$ Aichi/2/68 (H3N2) } & \multicolumn{2}{c|}{$\begin{array}{c}\text { A/chicken/Kurgan/05/200 } \\
5(\mathrm{H} 5 \mathrm{~N} 1)\end{array}$} \\
\cline { 3 - 6 } & & $\begin{array}{c}\operatorname{lgTCD}_{50} / \mathrm{mL} \pm \\
\mathrm{Sm}\end{array}$ & $\mathrm{NI}, \log$ & $\begin{array}{c}\operatorname{lgTCD}_{50} / \mathrm{mL} \\
\pm \mathrm{Sm}\end{array}$ & $\mathrm{NI}, \log$ \\
\hline $\begin{array}{c}\text { Dracocephalum } \\
\text { nutans }\end{array}$ & 1.0 & $6 \pm 0.29$ & 0.25 & $4.5 \pm 0.0$ & 1.75 \\
\hline $\begin{array}{c}\text { Glechoma } \\
\text { hederacea }\end{array}$ & 3.33 & $6 \pm 0.29$ & 0.25 & $2.5 \pm 0.0$ & 3.75 \\
\hline Melissa officinalis & 5.0 & $5 \pm 0.29$ & 1.25 & $3.0 \pm 0.29$ & 3.25 \\
\hline Berteroa incana & 1.0 & $6 \pm 0.29$ & 0.25 & $4.5 \pm 0.0$ & 1.75 \\
\hline $\begin{array}{c}\text { Aegopodium } \\
\text { podagraria }\end{array}$ & 2.5 & $5 \pm 0.29$ & 1.25 & $3.5 \pm 0.0$ & 2.75 \\
\hline Veronica longifolia & 2.5 & $4.5 \pm 0.0$ & 1.75 & $4.0 \pm 0.29$ & 2.25 \\
\hline Kонтроль & - & $6.25 \pm 0.25$ & - & $6.25 \pm 0.38$ & - \\
\hline
\end{tabular}

Note: $\log \mathrm{TCD} 50 / \mathrm{mL}$ is a decimal logarithm of $50 \%$ tissue cytopathic dose; Sm is standard deviation; NI is a virus neutralization index.

The neutralization index (NI) values for the inhibition of the H3N2 subtype under the action of the ethanol extracts of Glechoma hederacea, Berteroa incana, and Aegopodium podagraria were $3.25 \mathrm{log}, 4.25 \mathrm{log}$, and $4.75 \mathrm{log}$, respectively. The NI values for the inhibition of the H5N1 subtype under the action of the aqueous extracts of Glechoma hederacea, Melissa officinalis, Aegopodium podagraria, and Veronica longifolia were 3.75 $\log , 3.25 \mathrm{log}, 2.75 \mathrm{log}$, and $2.25 \mathrm{log}$, respectively. The NI values for the inhibition of the H5N1 subtype under the action of the ethanol extracts of Berteroa incana and Veronica longifolia were $3.25 \mathrm{log}$ and $2.75 \mathrm{log}$. The ethanol extract of Aegopodium podagraria and the aqueous extract of Glechoma hederacea were the most efficient against the H3N2 and H5N1 subtypes of IAV, respectively.

The identification of compounds, which are responsible for the biological activity of plants and preparations on their basis, is an important point for the standardization. We analyzed the literature data on the phytochemical composition of plants, which were efficient against the influenza virus.

The Berteroa incana herb contains phenolic compounds (primarily flavonoids, also phenolic acids, coumarins, and tannins), carbohydrates (water-soluble polysaccharides, pectin substances, and hemicelluloses A and B), triterpene saponins, organic acids, amino acids, carotenoids, and macro- and microelements [11, 12]. Aegopodium podagraria contains coumarins, flavonoids, hydroxycoric acids, tannin substances, water-soluble polysaccharides, ascorbic acid, and essential oil [13]. Flavonoids, iridoids, and tannins were found in the herb Veronica longifolia [14]. In the aboveground part of Glechoma hederacea L., gallic acid, catechin, epigallocatechin gallate, epicatechin, caffeic acid, dihydroquercetin, luteolin, luteolin-7-glycoside, apigenin, apigenin-7-glycoside, quercetin, and rutin were identified $[15,16]$. The herb Melissa officinalis is dominated by the flavonoids luteolin and rutin. The content of the sum of flavonoids in the raw material of medicinal melissa in terms of rutin is about 5\% [17]. Besides, phenolic compounds, such as rosemary acid (phenylpropanoid), cymaroside, and cosmosiin (7-O-glucosides of luteolin and apigenin, respectively) were revealed in raw materials of Melissa officinalis [18].

It was found that all the studied plants contain phenolic compounds including flavonoids. There are studies, which prove that flavonoids affect the antiviral activity of plants. For example, flavonoids from Alchemilla vulgaris exhibit antiviral activity against orthopoxviruses, influenza virus, and herpes simplex virus $[3,4,5]$. Chelepin, an extract of Lespedeza bicolor, that contains a natural amount of flavonoids, shows a virucidal activity 
when applied topically [19]. Flavonoids of Kaempferia parviflora can inhibit the protease activity of human immunodeficiency virus type 1 , hepatitis $\mathrm{C}$ virus, and cytomegalovirus [20]. Flavonoids, phenylpropanoids (for example, rosemary acid), and tannins of Melissa officinalis are active against herpes and influenza [21].

It should be recognized, however, that to reliably determine the groups of substances responsible for the antiviral effect of plant extracts, it is necessary to further isolate them from plants and analyze their biological activity. This will later allow one to establish reliable parameters for the standardization of developed drugs.

\section{Conclusions}

Glechoma hederacea, Melissa officinalis, Berteroa incana, Aegopodium podagraria, and Veronica longifolia have been shown to have antiviral activity against influenza A virus.

The ethanol extract of Aegopodium podagraria (IN 4.75) was the most active against the H3N2 subtype of IAV, and the water extract of Glechoma hederacea (IN 3.75) was the most active against the H5N1 subtype of IAV. The ethanol extract of Berteroa incana exhibits relatively high activity against influenza A virus of both subtypes.

The results suggest that the ethanol extracts of Aegopodium podagraria, and Berteroa incana and the aqueous extract of Glechoma hederacea are the most promising experimental samples for further research in vivo to develop new drugs for the prevention and treatment of influenza virus.

\section{References}

1. I.E. Lobanova, G.I. Vysochina, N.A. Mazurova, T.A. Kukushkina, E.I. Filippova, Chemistry of plant raw materials, 1, 130-136 (2019).

2. I.E. Lobanova, E.I. Filippova, G.I. Vysochina, N.A. Mazurkova, Rast. world of Asian Russia, 2, 64-72. (2016).

3. N.A. Mazurkova, T.A. Kukushkina, G.I. Vysochina, Zh. Ibragimova, I.E. Lobanova, E.I. Filippova, O.Yu. Mazurkov, E.V. Makarevich, L.N. Shishkina, A.P. Agafonov, Development and registration of medicinal products, 1, 118-127 (2016)

4. N.A. Mazurkova, M.A. Protsenko, E.I. Filippova, T.A. Kukushkina, G.I. Vysochina, I.E. Lobanova, O.Yu. Mazurkov, L.N. Shishkina, A.P. Agafonov, Development and registration of medicinal products, $\mathbf{8}, 14-20$ (2019)

5. E.I. Filippova, T.A. Kukushkina, I.E. Lobanova, G.I. Vysochina, N.A. Mazurkova, Fundamental research, 2-23, 5139-5144 (2015)

6. E.I. Filippova, I.E. Lobanova, O.Yu. Mazurov, G.I. Vysochina, N.A. Mazurkova, Fundamental aspects of compensatory and adaptive processes, 172-173 (2018)

7. M.A. Protsenko, N.E. Kostina, T.V. Teplyakova, Biotechnology, 34, 45-51 (2018)

8. R.U. Khabriev, Guide to the experimental (preclinical) study of new pharmacological substances: Handbook (2nd ed., reprint. and add. M.: Medicine, 2005)

9. L. Zaks, statistical evaluation (M.: Statistics, 1976)

10. A.A. Khalafyan, Statistica 6. Statistical analysis of data (2nd ed. M.: BinomPress, 2010)

11. I.L. Drozdova, T. I. Lupilina, Sorption and chromatographic processes, 13, 891-895 (2013)

12. I.L. Drozdova, T.I. Lupilina, Traditional medicine, 3, 29-34 (2018)

13. V.A. Ageev, A.V. Senkova, M.A. Khanina, T.A. Ageeva, Pharmacy, 6, 36-38 (2010)

14. N.F. Gusev, O.N. Americhina, proceedings of the Orenburg state agrarian University, 3, 258-261 (2008) 
15. E.A. Vasilenko, O.I. Popova, Scientific Bulletin of the Belgorod State University. Series: Medicine. Pharmacy, 16, 170-172 (2012)

16. D.I. Pisarev, O.O. Novikov, V.N. Sorokopudov, A.S. Shabelnikova, N. N. Netrebenko, Scientific Bulletin of the Belgorod State University. Series: Natural Sciences, 3, 179-185 (2011)

17. A.I. Marakhova, N.N. Fedorovsky, A.A. Sorokina, Pharmacy, 3, 10-11 (2007)

18. S.A. Kolesov, Student science and medicine of the XXI century: traditions, innovations, and priorities. Student spring Samara state medical University, 189-190 (2016)

19. S.A. Vichkanova, Chemistry, technology, medicine: Collection of scientific works, vol. 75th anniversary of the all-Russian Institute of medicine. and the aroma. plants, 480-484 (2006)

20. K. Sookkongwaree, M. Geitmann, S. Roengsumran, A. Petsom, U.H. Danielson, Pharmazie, 61, 717-721 (2006)

21. E.C. Herrmann, L.S. Kucera, Proc. Soc. Exp. Biol. Med. Mar., 124, 869-874 (1967) 